\title{
One hundred and one questions
}

\author{
Ros ALIND AVELING
}

What are the one hundred scientific questions that, if answered, would have the greatest impact on conservation practice and policy? A valiant attempt by Sutherland et al. (2009) to extract these questions from a mix of conservation practitioners and academics produced a fascinating list. Questions on ecosystem processes and species management were balanced by those on the societal context, behaviour of organizations, economic drivers and policy responses. The aim was to focus research on the evidence of most use to conservation management, and the result provides both a shopping list for research teams and a framework for granting bodies seeking investment value. By chance, the one hundredth question (there is no ranking) is 'What mechanisms best promote the use of local ideas and knowledge in conservation programmes in ways that enhance biodiversity outcomes?'

The complexity of local decision-making within conservation management has been extensively debated, as has the extent to which community livelihood strategies can be linked to conservation of natural areas. The cline of thinking is conveniently punctuated by the 5-year markers of IUCN gatherings. The Bangkok meeting in 2003 had a host of combatants trying to scale the ivory tower of the Back to the Barriers fundamentalists (Hutton et al., 2005). However, the framework for biodiversity conservation and the eradication of poverty put up by Adams et al. (2004) cut through this debate and positioned it as a choice of strategies appropriate to different contexts and driving forces. FFI had its own grappling irons on the tower, with a position on integrating local livelihood strategies with those for fauna and flora (FFI, 2006) and a field programme grown from local partnerships.

By the time of the Barcelona meeting in 2008 the tower was razed to the ground and pieces were being picked from the rubble to build a new paradigm. This recognizes the central role of local communities in preserving ecosystem services and that such communities may need support to secure governance over their local environment. The paradigm also places greater emphasis on global standards for human rights within conservation initiatives. As Leader-Williams points out (Leader-Williams \& Smith, in press) conservation is a social process guided by science, not a scientific process per se. That one hundredth question indicates that this is being recognized and that research is re-focusing on just how local knowledge can be translated into better outcomes for biodiversity within modern conservation practice.

But is the social science of conservation keeping up with the speed of change in our natural environment? Not

Rosalind Aveling Fauna \& Flora International, Jupiter House, Station Road, Cambridge, CB1 2JD, UK. E-mail rosalind.aveling@fauna-flora.org really-the UK Natural Environment Research Council positioned its 2007-2012 strategy (NERC, 2007) around understanding the role of biodiversity in key ecosystem processes, including thresholds for extinction and assessing the value of biodiversity to society. This is in the right direction but the evidence emerging needs to influence improved conservation practice at a speed and scale that will arrest decline. Substantive reviews are starting to bring into the public domain evidence of the speed at which our environment is changing, and the implications for society. The Stern Review (2006) brought the economic implications of a changing climate to the fore and the TEEB review (Sukhdev, 2008) will similarly bring to public attention the links between biodiversity and food security. The notoriously fickle attention of the public will not, however, remain focused on the implications unless we can keep the media's attention alive.

With respect to all the questions yet to be answered there is a risk that both researchers and practitioners will consume their energy in a self-indulgent feedback loop, allowing our natural environment to disappear when we should actually be shouting from the increasingly hot mountain tops. If we are not careful we will find ourselves assiduously monitoring the decline of endlessly fascinating biological diversity rather than applying both brains and brawn to ensuring that it can persist and evolve. Mwangi Githiru (2007) argued that conservation research can guide conservation strategies but that researchers and practitioners are the converted and we need, therefore, to influence the unconverted 'without letting the perfect get in the way of the possible'. So who are these unconverted whose decisions we need to try and influence on behalf of global biodiversity and ecosystem services-and how do we do it?

Are they landowners? Rarely-where ownership of land or rights to wildlife is clear and secure, persistence and diversity are usually factored into decision-making. Where these rights are not clear, or are uncertain, the door is open to opportunism and corruption, with short-term decision making or profiteering holding sway. In this situation re-enforcing traditional rights and frameworks for local environmental governance can improve the prospects for management actions that enhance persistence of species and ecosystem services.

Are they corporate captains? Clearly-and we need to ensure we are providing the data and arguments that can influence investors, shareholders and customers. We need to translate the relevant research into corporate language, creating the business case for biodiversity and demonstrating how the risks of poor biodiversity management can be 
minimized throughout supply chains. Corporate Social Reporting has made it into boardrooms and Corporate Environmental Reporting is beating on boardroom doors but managing biodiversity risk is still waiting to be noticed.

Are they legislators? Certainly-but voted in by an electorate that may also be in the dark. Although the evidence for the terrifying rate and scale of biodiversity loss is seeping into public consciousness with each new report on declining species, changing climate, declining forest cover and issues of food security, neither political nor public response is proportionate.

If you are reading Oryx you are one of the converted, so how can you influence those with less vision or short-term self interest? The Duke of Wellington's 'publish and be damned' is now publish or be damned. Publish your findings and package them into stories that connect people to the issues. Promote your stories through the popular press and feed them into social networking vehicles and policy briefs. Proselytise the fundamental nature of the crisis affecting us and provide the evidence from which lifelines can be fashioned. If we do not take this chance, by the time of the next IUCN gathering in 2013 we may be looking back in regret at the lost opportunities and options.

So yes, we must tackle those one hundred questions, and more. We must generate the evidence base. But my one hundred and first question, excluded from the one hundred as resistant to scientific enquiry, asks: How can we can turn conservation scientists into better communicators? Can we summon the clarity, candour, credibility and conviction to make a cogent case for biological diversity before its absence speaks louder than any words?

\section{References}

Adams, W.M., Aveling, R., Brockington, D., Dickson, B., Elliott, J., Hutton, J. et al. (2004) Biodiversity conser- vation and the eradication of poverty. Science, 306, 11461149 .

FFI (Fauna \& Flora International) (2006) The Case for Integrating Conservation and Human Needs. Livelihoods and Conservation in Partnership 1, FFI, Cambridge, UK.

Githiru, M. (2007) Conservation in Africa: but for whom? Oryx, 41, 119-120.

Hutton, J., Adams, W.M. \& Murombedzi, J.C. (2005) Back to the barriers: changing narratives in biodiversity conservation. Forum for Development Studies, 32, 341-371.

Leader-Williams, N. \& Smith, R. (eds) (in press) Trade Offs in Conservation. Blackwell, Oxford, UK.

NerC (Natural Environment Research Council) (2007) Next Generation Science for Planet Earth: NERC Strategy 2007-2012. NERC, Swindon, UK.

Stern, N. (2006) The Economics of Climate Change: The Stern Report. HM Treasury, London, UK.

SuKHdev, P. (2008) The Economics of Ecosystems \& Biodiversity: An Interim Report. Http://ec.europa.eu/environment/nature/ biodiversity/economics/pdf/teeb_report.pdf [accessed 24 June 2009].

Sutherland, W.J., Adams, W.M., Aronson, R.B., Aveling, R., BlACKBURN, T.M., BROAD, S. et al. (2009) One hundred questions of importance to the conservation of global biological diversity. Conservation Biology, 23, 557-567.

\section{Note from the Editor-New submission system}

Increasing awareness of the urgency of biodiversity conservation is certainly matched by the continued increase in manuscripts submitted to Oryx. To allow us, therefore, to continue to provide an efficient service to both authors and peer reviewers the journal now has a new online submission system, at mc.manuscriptcentral.com/oryx. All article types for submission to the journal, including Conservation News items, now need to be submitted through this site. For those requiring further advice and help on the submission process, further details are, as always, available on the journal's website at www.oryxthejournal.org or from the Editorial Office (oryx@fauna-flora.org). 